\title{
Tema dan Gaya Bahasa Puisi Siswa SMP: Kajian Struktural
}

\author{
Journal of Language learning \\ and Research (JOLLAR) \\ 2018, Vol. 2(2) 1-11 \\ (C) Author, 2018 \\ DOI: $10.22236 / J O L L A R \quad 2(2) 1-11$
}

\author{
Ahmad Hidayatullah ${ }^{1}$ \\ SMP Islam Daar El Arqam Tangerang
}

Penelitian ini bertujuan untuk menemukan data tentang tema serta gaya bahasa yang terdapat dalam sejumlah puisi karya siswa kelas VIII SMP Islam Daar El Arqam Tangerang. Metode yang digunakan dalam penelitian ini adalah metode kualitatif dengan teknik struktural. Berdasarkan hasil penelitian dapat diketahui, bahwa tema dalam puisi siswa kelas VIII SMP Islam Daar El Arqam meliputi tema tingkat fisik sebanyak 2 buah, tema tingkat organik sebanyak 1 buah, tema tingkat sosial sebanyak 12 buah, tema tingkat egoik sebanyak 5 buah, dan tema tingkat divine sebanyak 7 buah. Gaya bahasa dalam puisi puisi siswa kelas VIII SMP Islam Daar El Arqam yang meliputi gaya bahasa metafora sebanyak 1 buah, gaya bahasa simile sebanyak 7 buah, gaya bahasa personifikasi sebanyak 4 buah, gaya bahasa metonimi sebanyak 1 buah, gaya bahasa sinekdos sebanyak 1 buah, gaya bahasa hiperbola sebanyak 18 buah, gaya bahasa retoris sebanyak 4 buah, gaya bahasa repetisi sebanyak 8 buah, gaya bahasa paralelisme sebanyak 20 buah, dan gaya bahasa paradoks sebanyak 3 buah. Hasil penelitian ini dapat digunakan sebagai salah satu media pembelajaran tentang apresiasi puisi untuk siswa SMP.

Kata kunci: Puisi, tema, dan gaya bahasa

This study aimed to find the theme and style of language contained in a number of poems by students of class VIII SMP Islam Daar El Arqam Tangerang. It used qualitative method with structural technique. The results showed that the theme found in the students' poetry included 2 physical themes, 1 organic theme, 12 social themes, 5 egoic themes, and 7 divine theme. Language styles used in the writing included 1 metaphor style, 7 simile styles, 4 personi styles, 4 metonymic styles, 1 sinekdos style, 18 hyperbole styles, 4 rhetorical styles, 8 replica styles, 20 parallelism languages, and 3 paradoxes. The results of this study can be used as one of the learning media about poetry appreciation for junior high school students.

Keywords: Poetry, theme, and style of language

${ }^{1}$ Corresponding author: ahmadhidayatullah@gmail.com 


\section{PENDAHULUAN}

Tema merupakan gagasan pokok penyair lewat puisinya. Gagasan pokok inilah yang kemudian akan berkembang melalui penjelasan-penjelasan dan hubungan setiap kata dalam puisi tersebut, dari tema inilah yang akan menjadi kerangka pengembangan puisi.Tema juga berfungsi sebagai landasan utama penyair dalam puisinya. Jika landasan utamanya mengenai ketuhanan, maka seluruh struktur puisi itu tidak akan lepas dari renungan atau dialog dengan tuhan. Begitu pun jika landasan utamanya mengenai kemanusiaan, maka seluruh struktur puisi tersebut tidak akan jauh pula dan tidak akan mungkin lepas dari sosial masyarakat, baik dalam hubungan sosial, citra sosial, strata sosial, maupun sosialisasi lainnya.

Kata-kata yang dipilih oleh penyair sangatlah menentukan perasaan dan suasana puisi. Untuk itu, diperlukan ketelitian penyair dalam memilih kata untuk mewakili gagasan atau perasaannya. Kata-kata memiliki kedudukan yang sangat penting dalam puisi. Kata-kata yang dihasilkan dan digunakan oleh penyair harus seirama dengan suasana tema yang dibuatnya, guna terdapat keselarasan antara diksi dan isi puisi, sehingga pembaca dapat menikmati dan menangkap perasaan atau pikiran penyair lewat puisi yang dibuatnya.

Kata-kata yang dipilih oleh penyair sangat penting, karena hal ini juga akan memengaruhi gaya bahasa penyair itu sendiri. Rangkaian kata atau kumpulan kata yang dihasilkan oleh penyair akan membentuk gaya bahasanya sendiri. Dari sinilah, akan terlihat keindahan puisi dalam ciri khas penyairnya.

Gaya bahasa yang dihasilkan penyair janganlah membosankan. Hal inilah yang cenderung pembaca malas untuk membaca puisi. Dianggapnya puisi dengan gaya bahasa yang membosankan ini tidak berkualitas atau tidak bermutu. Gunakan gaya bahasa yang tepat dan bervariasi guna dapat menghibur pembaca. Seorang penyair harus mampu memilih gaya bahasa yang bukan biasa, melainkan gaya bahasa yang cenderung estetis, yang belum terbiasa terdengar atau gaya bahasa yang mampu menyentuh hati pembaca. Hal inilah yang menjadi tujuan dalam gaya bahasa yaitu memberikan keindahan dalam bahasa puisi.

Kemampuan penyair dalam penguasaan gaya bahasa juga sangat menentukan keindahan, perasaan, kehidupan, nuansa, dan jiwa puisi yang dibuatnya. Puisi yang dibuat akan memiliki daya tarik tersendiri tergantung kepada kelenturan gaya bahasa penyairnya. Hal inilah yang akan menjadi ciri khas penyair dalam menimbulkan keindahan di dalam puisinya. Dengan ciri khas yang ada, penyair akan memiliki nilai tersendiri dan berbeda dengan penyair lainnya.

Dalam pembelajaran puisi di SMP, puisi yang diciptakan tentu harus memiliki tema yang sesuai dengan minat siswa tersebut. Tema puisi yang diciptakan, tentunya tema yang disenangi siswa-siswi menurut usia maupun tingkatan kelasnya masingmasing. Seorang guru harus cermat ketika melakukan pembelajaran puisi, pilih tematema yang disenangi oleh siswa atau tema-tema yang sedang populer dan ramai 
dibicarakan di kalangan siswa, khususnya siswa SMP. Dengan ketertarikan siswa tematema tersebut, maka akan mempermudah dan mendorong siswa lebih semangat lagi dalam berpuisi.

Selain pengembangan tema, melalui pembelajaran puisi, siswa dapat berlatih mengembangkan pikiran-pikiran atau ide-idenya dengan memilih kata setepat-tepatnya agar gagasannya sampai pada bahasa yang mudah diterima dan dipahami oleh pembaca. Selain itu, rangkaian kata-kata yang digunakan tersebut dibuat dan dikemas dengan gaya penyair tersendiri sedemikian rupa guna menimbulkan kesan yang mendalam melalui puisi yang dibuatnya. Hal ini termasuk juga dalam mengembangkan kemampuan bahasanya melalui diksi dan gaya bahasa puisi.

Potensi pembelajaran puisi sebagai alat untuk belajar dan mengembangkan bahasa memang sangat besar. Namun, dalam aplikasi pembelajaran puisi di kelas maupun dalam kehidupan sehari-hari, berpotensi puisi itu dirasa kurang bermakna. Kadang siswa menganggap pembelajaran puisi sebagai pelajaran yang rumit, membosankan, dan tidak penting. Mungkin hal ini bisa disebabkan dari faktor guru ketika pembelajaran puisi memilih temanya dirasa kurang menarik bahkan biasa-biasa saja, atau mungkin diksi yang dipilih guru terlalu sulit atau asing bagi mereka, atau mungkin pula gaya bahasa yang digunakan atau diajarkan guru dalam pengajaran maupun contoh puisinya sangat minim, sehingga siswa jenuh harus bergelut dengan gaya bahasa itu-itu lagi. Hal inilah yang cenderung mengantarkan siswa kepada kemalasan dan menganggap pembelajaran puisi itu tidak penting dan membosankan.

Dalam melihat kasus tersebut, penulis tertarik untuk meneliti tema dan gaya bahasa puisi yang dibuat oleh siswa-siswa SMP. Dalam hal ini, penulis ingin melihat tingkat perkembangan tema-tema yang dipakai/diminati siswa, serta variasi gaya bahasa yang dipakai dalam menciptakan puisi siswa tersebut menjadi lebih estetis dalam mewakili perasaan atau pikirannya.

Masalah dalam penelitian ini yaitu bagaimana tema dan gaya bahasa puisi karya siswa kelas VIII SMP Islam Daar El Arqam Tangerang (Kajian Struktural)? Di samping masalah, ada pula tujuan yang melandasi guna menyelesaikan masalah tersebut Tujuan dalam penelitian ini adalah untuk mengetahui tema dan gaya bahasa puisi karya siswa kelas VIII SMP Islam Daar El Arqam Tangerang berdasarkan kajian struktural.

Berdasarkan uraian di atas, penulis tertarik mengadakan penelitian mengenai tema, diksi, dan gaya bahasa pada puisi yang dianalisis secara struktural. Untuk itu, penulis mengambil judul "Tema dan gaya bahasa puisi karya siswa kelas VIII SMP Islam Daar El Arqam Tangerang (Kajian Struktural)."

Berdasarkan uraian di atas, penulis tertarik mengadakan penelitian mengenai tema, diksi, dan gaya bahasa pada puisi yang dianalisis secara struktural. Untuk itu, penulis mengambil judul "Tema dan gaya bahasa puisi karya siswa kelas VIII SMP Islam Daar El Arqam Tangerang (Kajian Struktural)." 


\section{Hakikat Tema}

Tema berasal dari bahasa Yunani tithenia yang berarti 'menempatkan' atau 'meletakkan.' Menurut arti katanya "sesuatu yang telah diuraikan" atau "sesuatu yang telah ditempatkan." Arti tema ini kemudian dipertegas oleh Keraf (1994: 107-108), bahwa tema adalah suatu perumusan dan topik yang akan dijadikan landasan pembicaraan dan tujuan yang akan dicapai melalui topik.

Pendapat di atas mengisyaratkan, tema sebagai landasan pembicaraan yang dituangkan melalui topik. Topik atau pokok pembicaran ini menempatkan suatu tujuan yang ingin disampaikan oleh penulis. Dengan mengemukakan topik, berarti penulis sudah mengemukakan maksud dan tujuan pembicaraan. Di samping itu, dengan mengemukakan topik yang telah dibatasi oleh tujuan tersebut, maka perhatian pembicara/penulis lebih terpusat sehingga tetap bergulat dengan persoalan yang hendak disampaikan.

Finoza (2008: 215) mempertegas bahwa tema adalah pokok pikiran, ide, atau gagasan tertentu yang akan melatarbelakangi dan mendoorong seseorang menuliskan karangannya. Dengan demikian, jika seseorang memikirkan sesuatu atau menentukan tema, tentulah terkandung maksud tujuan atau sasaran tertentu. Hal inilah yang mendasari latar belakang tersebut (maksud, tujuan, sasaran) dituangkan ke dalam tulisannya.

Terkait mengenai hakikat tema sebagai gagasan sentral, Baribin dalam Wahyuningtyas dan Wijaya (2011: 2-3), menjelaskan bahwa tema merupakan gagasan sentral, sesuatu yang hendak diperjuangkan dalam suatu tulisan atau karya fiksi. Hal ini jelas bahwa, tema merupakan gagasan utama atau gagasan sentral penulis dalam karya yang dibuatnya berdasarkan tujuan-tujuan yang hendak disampaikan oleh penyair atau penulis.

Pengertian tema dipertegas kembali oleh Lord dalam Taum (2011: 103-104), bahwa tema adalah sejumlah ide atau kelompok-kelompok ide yang secara teratur digunakan dalam penceritaan. Dengan kata lain, tema terdiri atas sejumlah ide atau kelompok-kelompok ide yang dituangkan dalam sebuah karya. Dengan demikian, tema tidak hanya bisa dirangkai melalui rangkaian kata-kata saja, melainkan kelompokkelompok ide atau kelompok gagasan yang mendukung tujuan pembicaraan. Hal ini dilakukan agar tema itu menjadi dan lebih hidup.

Shipley membedakan tema dalam lima tingkatan, yaitu 1)tema tingkat fisik, yaitu tema yang merujuk kepada banyaknya aktivitas fisik daripada kejiwaan, misalnya Around the World in Eight Days karya Julius Verne; 2)tema tingkat organik, yaitu yang menyangkut atau mempersoalkan masalah seksualitas-suatu aktivitas yang hanya dapat dilakukan oleh makhluk hidup, misalnya karya-karya Muchtar Lubis, seperti Maut dan Cinta, Tanah Gersang, Jalan Tak Ada Ujung; 3)tema tingkat sosial, yaitu tema yang merujuk pada permasalahan/konflik manusia dengan sesama dan dengan lingkungan alam berupa masalah ekonomi, politik, pendidikan, budaya, perjuangan, cinta kasih, 
propaganda, hubungan atasan-bawahan, dan berbagai masalah dan hubungan sosial lainnya yang biasa muncul dalam karya yang berisi kritik sosial, misalnya Kemelut hidup, Ronggeng dukuh Paruk, Royan Revolusi, dan lain-lain; 4)tema tingkat egoik, yaitu tema yang merujuk makhluk individu dengan berbagai permasalahan/konflik berupa reaksi manusia terhadap masalah-masalah sosial yang dihadapinya, misalnya Atheis, Jalan Tak Berujung, Gairah untuk Hidup dan Mati, Malam Kualalumpur, dan sebagainya; 5)tema tingkat divine, yaitu tema yang merujuk pada masalah manusia dengan Sang Pencipta, masalah religiositas, atau berbagai masalah yang bersifat filosofis lainnya seperti pandangan hidup, visi, dan keyakinan, misalnya Robohnya Surau Kami, Datangnya dan Perginya, Kemarau, dan sebagainya.

Berdasarkan pengertian tema dari beberapa para ahli, dapat disimpulkan bahwa tema puisi adalah kumpulan ide atau kelompok-kelompok ide atau perasaan yang membentuk gagasan sentral melalui topik pemikiran atau topik pembicaraan berdasarkan maksud dan tujuan yang hendak penyair sampaikan dalam puisi yang dibuatnya, baik secara eksplisit (tersurat) maupun implisit (tersirat) yang disajikan sesuai dengan berbagai makna kehidupan ataupun pengalaman hidup penyair itu sendiri.

\section{Hakikat Gaya Bahasa}

Kata-kata yang digunakan oleh penyair dalam mewakili atau mengekspresikan perasaan dan isi pikirannya melalui puisi yang dibuatnya akan menimbulkan gaya bahasa penulis itu sendiri. Kata-kata yang terangkai menjadi frase, klausa, ataupun kalimat itu akan membentuk gaya bahasa. Gaya bahasa inilah yang akan menjadi ciri khas penyair.

Terkait mengenai gaya bahasa, Keraf (2007:133) menjelaskan bahwa gaya bahasa adalah cara mengungkapkan pikiran melalui bahasa secara khas yang memperlihatkan jiwa dan kepribadian penulis (pemakai bahasa). Bahasa yang ditampilkan penyair dalam puisinya akan menjadi ciri khas penyair itu sendiri. Untuk itu, seorang penyair harus mampu menghidupkan bahasanya melalui gaya bahasa yang digunakannya.

Gaya bahasa itu digunakan untuk menimbulkan reaksi tertentu, menimbulkan tanggapan pikiran kepada pembaca. Hal inilah yang menjadi tujuan utama gaya bahasa itu dipakai. Gaya bahasa yang digunakan harus ditampilkan atau mengandung bahasa yang indah agar mampu membangkitkan reaksi dan tanggapan dari pembaca.

Nurgiyantoro (2009: 297) memberikan batasan arti gaya bahasa. Gaya bahasa adalah gaya pengarang/penyair yang sengaja mendayagunakan penuturan dengan memanfaatkan bahasa kias. Dengan demikian, gaya bahasa merupakan teknik pengungkapan bahasa seorang penyair dalam penggayabahasaan yang maknanya tidak menunjukan makna harfiah kata-kata yang mendukungnya, melainkan pada makna yang ditambahkan menjadi makna yang tersirat. 
gaya merupakan ciri khas atau ciri pribadi seorang pengarang/penyair dalam mengungkapkan sesuatu secara khas mengenai suatu hal atau cerita. Melalui gaya inilah akan mempengaruhi gaya bahasa penyair. Gaya bahasa yang ditampilkan dengan bahasa yang indah itu harus mampu menimbulkan efek atau reaksi tertentu sebagai wujud tanggapan dari perasaan pembaca setelah membaca karya tersebut. untuk menimbulkan efek atau reaksi tersebut, maka gaya bahasa yang digunakan penyair harus mampu menggerakkan dan menimbulkan reaksi ari pembaca sehingga pesan atau informasi dalam karya tersebut dapat terapresiasi dengan baik. Reaksi tersebut dapat berupa tanggapan, menyakini atau mempengaruhi pembaca. Hal ini sejalan dengan pendapat yang dikemukakan oleh Tarigan (2009:4) menyatakan, bahwa gaya bahasa adalah bentuk retorik, yaitu penggunaan kata-kata dalam berbicara dan menulis untuk menyakinkan atau mempengaruhi penyimak dan pembaca. Dengan demikian, gaya bahasa yang baik ialah gaya bahasa yang dapat menyakinkan atau mempengaruhi pembaca/penyimak atau gaya bahasa yang dapat menimbulkan efek atau rekasi tertentu dengan baik.

Berdasarkan pendapat para ahli di atas, dapat disimpulkan bahwa gaya bahasa adalah gaya seorang penyair/penulis dalam menyampaikan isi pikiran atau perasaannya dengan memanfaatkan kata-kata atau bahasa yang indah sesuai dengan sifat dan kegemaran individu penyair/penulis itu sendiri dalam rangka mencoba menyakinkan atau mempengaruhi penyimak dan pembaca terhadap karya yang dibuatnya.

\section{Hakikat Pendekatan Struktural}

Teori struktural mencoba mengungkapkan secara cermat keterkaitan semua unsur karya sastra yang secara bersama-sama menghasilkan makna menyeluruh. Di dalam ilmu sastra pengertian "strukturalisme" digunakan untuk berbagai macam cara. Struktur adalah kaitan-kaitan tetap antara kelompok-kelompok gejala. Kaitan-kaitan tersebut diadakan oleh peneliti berdasarkan observasinya. Karya sastra dibangun dari suatu struktur, terutama struktur bahasa. Hasil karya sastra itu merupakan satu kesatuan, keseluruhan, atau kebulatan. Hasil karya sastra tersebut merupakan sebuah struktur yang terjalin dari bagian-bagian atau unsur-unsur hasil karya sastra.

Taum (1994: 282) memperjelas bahwa analisis struktural menekankan fungsi karya sastra sebagai sebuah struktur yang otonom, atau sastra ditentukan oleh aspekaspek atau bagian-bagian karya sastra tersebut. Dengan demikian, dapat disimpulkan bahwa langkah awal dalam melakukan penelitian sastra ialah mengadakan analisis struktural sebagai langkah awal menentukan fungsi karya sastra sampai menemukan makna keseluruhan dari karya sastra yang dikaji/dianalisis.

Teori struktural ini dapat dipandang sebagai salah satu pendekatan kesastraan yang menekankan pada kajian hubungan natarunsur yang satu dengan unsur yang lainnya secara padu dalam membangun karya sastra. Sebuah karya sastra dibangun dan ditegaskan serta digambarkan melalui hubungan antarunsurnya yang telah membentuk 
satu kesatuan yang utuh. Melalui hubungan struktur itulah, karya sastra dapat lebih berarti dan lebih penting.

Sebuah karya sastra menurut teori struktural ini merupakan sebauh totalitas yang dibangun secara koherensif oleh berbagai unsur sastra serta hubungannya dengan unsur lainnya. Struktur karya sastra memperjelaskan berbagai pengertian hubungan antarunsur (struktur pembangun) yang bersifat timbal-balik, saling menentukan, saling mempengaruhi, yang secara bersama membentuk satu kesatuan utuh.

Teori struktural ini merupakan tahap awal dalam penelitian sastra yang tak bisa dihindarkan. Teew dalam Taum (1994: 283) mempertegas bahwa analisis struktur merupakan sebuah tahap penelitian dan merupakan prasyarat bagi pengkajian sastra lainnya. Dengan demikian, bisa diartikan bahwa dalam melakukan penelitian sastra, untuk mengungkapkan makna atau pengertian secara keseluruhan maka harus dimulai terlebih dahulu melalui analisis struktur. Melalui analisis struktur inilah bisa ditemukan makna atau pengertian yang terkait dengan unsur-unsur pembangunnya.

Struktural berarti deskripsi struktur-struktur. Jika dikaitkan dengan puisi, struktural puisi adalah analisis puisi ke dalam unsur-unsurnya dan fungsinya dalam struktur puisi. Jadi, puisi merupakan struktur. Struktur di sini berarti susunan unsurunsur yang bersistem yang sering terjadi hubungan timbal balik dan saling menentukan.

Unsur-unsur yang dimaksud ialah struktur puisi. Struktur puisi terdapat dua bagian, yaitu struktur fisik dan struktur bathin. Djojosuroto (2005: )menjelaskan bagian-bagian struktur tersebut. Struktur Fisik terdiri atas diksi, bahasa kias/gaya bahasa/majas (figurative language), pencitraan (imagery), persajakan (rima, titma, metrum). Sedangkan, struktur bathin terdiri atas tema, nada (tone), suasana (atmosphere), dan amanat (message).

Analisis struktural karya sastra, dapat dilakukan dengan mengidentifikasi, mengkaji dan mendeskripsikan fungsi dan hubungan antarunsur pembangun karya sastra yang bersangkutan. Mula-mula diidentifikasi dan dideskripsikan setiap unsur pembangunnya. Setelah itu, dijelaskan bagaimana fungsi-fungsi masing-masing unsur itu dalam menunjang makna keseleuruhannya, dan baagimana hubungan antarunsur itu sehingga secara bersama-sama membentuk sebuah totalitas kemaknaan yang padu.

Tujuan utama analisis struktural adalah untuk membongkar dan memaparkan secermat, seteliti, semendalam mungkin, keterkaitan dan keterjalinan semau anasir dan aspek karya sastra secara bersama-sama hingga menghasilkan makna menyeluruh. Dengan membongkar dan memaparkan secermat mungkin setiap hubungan unsur dan keterkaitan tiap unsurnya, maka akan mempermudah mengarahkan pada makna cerita secara keseluruhan.

Berdasarkan pendapat para ahli di atas, dapat disimpulkan bahwa teori/kajian struktural adalah suatu kajian yang mencoba mengungkapkan secara cermat keterkaitan semua unsur karya sastra yang secara bersama-sama dalam menghasilkan makna menyeluruh. Kaitan unsur sastra tersebut dapat dipahami berdasarkan bentuk 
struktur sastra serta hubungan natarunsur yang satu dengan unsur yang lainnya secara padu dalam membangun karya sastra.

\section{METODOLOGI}

Metode yang digunakan dalam penelitian ini adalah metode kualitatif dengan teknik analisis isi. Penelitian ini semata-mata hanya berdasarkan pada fakta dan data yang diperoleh dari puisi siswa. Dengan metode kualitatif, peneliti hanya menganalisis data berdasarkan unsur-unsur puisi (tema dan gaya bahasa), kemudian memaparkan, dan menyimpulkannya.

Data diambil berdasarkan puisi yang dibuat oleh siswa kelas VIII SMP Islam Daar El Arqam Tangerang yang kemudian dianalisis tiap larik puisi tersebut berdasarkan tema dan gaya bahasa puisi. Data yang dianalisis yaitu larik-larik puisi berupa kata, kumpulan kata, kalimat, dan wacana (larik puisi secara keseluruhan). Berdasarkan kata, kumpulan kata, kalimat, dan wacana (larik puisi secara keseluruhan) ini, penulis menganalisisnya kemudian memaparkan, dan menyimpulkannya secara sistematis. Dalam menganalisis, penulis mencoba menganalisis tiap larik puisi yang dibuat siswa guna menemukan struktur puisi khususnya tema, diksi, dan gaya bahasa puisi.

Data yang dikumpulkan ialah struktur puisi yang mencakupi tema dan gaya bahasa. Adapun, sumber datanya adalah larik-larik puisi yang ditulis oleh siswa kelas VIII SMP Islam Daar El Arqam Tangerang.

Selanjutnya, analisis dalam penelitian ini berpedoman pada pendapat Miles dan Haberman. Miles dan Huberman. Miles dan Huberman dalam Emzir (2010: 129-133) mengemukakan, "Analisis data dilakukan dengan tiga proses yang berkesinambungan, yaitu reduksi data, penyajian model data (Data Display), dan penarikan atau verifikasi kesimpulan." Tiga tahap ini dilakukan dalam penelitian kualitatif dan berkesinambungan dalam tiap tahapnya, diawali dengan tahap reduksi data, yaitu pemilihan, pemfokusan, penyederhanaan, abstraksi, dan pentransformasian data yang terjadi dalam catatan-catatan lapangan tertulis. Kemudian dilanjutkan dengan model data (Data Display) yaitu penyajian data untuk mendeskripsikan kesimpulan dan pengambilan tindakan. Setelah reduksi data dan model data telah selesai, maka dilanjutkan dengan penarikan atau verifikasi kesimpulan untuk memutuskan kesimpulan akhir dari data yang dianalisis dalam penelitian.

\section{HASIL PENELITIAN}

Tema dalam puisi puisi siswa kelas VIII SMP Islam Daar El Arqam berjumlah 27 buah, sedangkan gaya bahasa dalam puisi puisi siswa kelas VIII SMP Islam Daar El Arqam sebanyak 67 buah.

Di samping itu, dapat diketahui pula tema dalam puisi puisi siswa kelas VIII SMP Islam Daar El Arqam meliputi tema tingkat fisik sebanyak 2 buah, tema tingkat 
fisik sebanyak 2 buah, tema tingkat organik sebanyak 1 buah, tema tingkat sosial sebanyak 12 buah, tema tingkat egoik sebanyak 5 buah, dan tema tingkat divine sebanyak 7 buah. Kemudian diketahui pula, gaya bahasa dalam puisi puisi siswa kelas VIII SMP Islam Daar El Arqam yang meliputi gaya bahasa metafora sebanyak 1 buah, gaya bahasa simile sebanyak 7 buah, gaya bahasa personifikasi sebanyak 4 buah, gaya bahasa metonimi sebanyak 1 buah, gaya bahasa sinekdos sebanyak 1 buah, gaya bahasa hiperbola sebanyak 18 buah, gaya bahasa retoris sebanyak 4 buah, gaya bahasa repetisi sebanyak 8 buah, gaya bahasa paralelisme sebanyak 20 buah, dan gaya bahasa paradoks sebanyak 3 buah.

Dengan demikian dapat disimpulkan bahwa tema dalam puisi puisi siswa kelas VIII SMP Islam Daar El Arqam yang paling banyak diminati siswa ialah tema tingkat sosial sebanyak 12 buah. Sedangkan, gaya bahasa dalam puisi puisi siswa kelas VIII SMP Islam Daar El Arqam yang paling banyak muncul ialah gaya bahasa paralelisme sebanyak 20 buah.

Berdasarkan kesimpulan di atas, siswa kelas VIII SMP Islam Daar El-Arqam lebih banyak berminat pada tema-tema yang mengandung unsur sosial atau tema tingkat sosial. Tema tingkat sosial merupakan tema yang merujuk pada permasalahan/konflik manusia dengan sesama dan dengan lingkungan alam berupa masalah ekonomi, politik, pendidikan, budaya, perjuangan, cinta kasih, propaganda, hubungan atasan-bawahan, dan berbagai masalah dan hubungan sosial lainnya yang biasa muncul dalam karya yang berisi kritik sosial.

Tema-tema tingkat sosial yang siswa kelas VIII minati dalam membuat puisi seperti hubungan dirinya dengan ibu, ayah, keluarga, ataupub lingkungan sekitarnya. Dalam penelitian ini, dengan melihat hasil puisi yang dibuat siswa kelas VIII SMP Islam Daar El Arqam lebih merujuk pada tema ibu dan sahabat.

Dalam pembuatan puisi, siswa cenderung menggunakan gaya bahasa sebagai daya tarik dari puisi yang dibuatnya. Salah satu daya tarik yang siswa tonjolkan dalam puisi yang dibuatnya ialah dengan menggunakan gaya bahasa paralelisme. Gaya bahasa paralelisme yaitu gaya bahasa dengan pengulangan yang sering dipakai dalam puisi.

Dalam pembentukannya, gaya bahasa paralelisme ini dibentuk melalui 2 gaya bahasa, yaiitu gaya bahasa paralelisme anafora dan efifora. Gaya bahasa anafora, yaitu gaya bahasa pengulangan kata atau kelompok kata pada bagian awal puisi atau lagu. Sedangkan, gaya bahasa epifora, yaitu gaya bahasa penegasan dengan pengulangan kata atau kelompok kata pada bagian akhir puisi atau lagu.

Gaya bahasa paralelisme yang digunakan siswa ke dalam puisi yang dibuatnya bermaksud untuk menghasilkan gaya khas tersendiri serta menegaskan maksud dari puisi yang dibuatnya. Gaya bahasa paralelisme yang digunakan siswa dalam puisi yang dibuatnya lebih banyak menegaskan kepada gaya bahasa anafora, yaitu gaya bahasa pengulangan kata atau kelompok kata pada bagian awal puisi. 


\section{KESIMPULAN}

Berdasarkan temuan dan pembaahasan yang telah diutarakan pada bagian sebelumnya, selanjutnya berikut ini diutarakan beberapa simpulan serta rekomendasi yang dapat ditujukan kepada beberapa pihak yang berkaitan. tema dalam puisi puisi siswa kelas VIII SMP Islam Daar El Arqam meliputi tema tingkat fisik sebanyak 2 buah, tema tingkat fisik sebanyak 2 buah, tema tingkat organik sebanyak 1 buah, tema tingkat sosial sebanyak 12 buah, tema tingkat egoik sebanyak 5 buah, dan tema tingkat divine sebanyak 7 buah.

Kemudian diketahui pula, gaya bahasa dalam puisi puisi siswa kelas VIII SMP Islam Daar El Arqam yang meliputi gaya bahasa metafora sebanyak 1 buah, gaya bahasa simile sebanyak 7 buah, gaya bahasa personifikasi sebanyak 4 buah, gaya bahasa metonimi sebanyak 1 buah, gaya bahasa sinekdos sebanyak 1 buah, gaya bahasa hiperbola sebanyak 18 buah, gaya bahasa retoris sebanyak 4 buah, gaya bahasa repetisi sebanyak 8 buah, gaya bahasa paralelisme sebanyak 20 buah, dan gaya bahasa paradoks sebanyak 3 buah. Tema dalam puisi puisi siswa kelas VIII SMP Islam Daar El Arqam yang paling banyak diminati siswa ialah tema tingkat sosial sebanyak 12 buah. Sedangkan, gaya bahasa dalam puisi puisi siswa kelas VIII SMP Islam Daar El Arqam yang paling banyak muncul ialah gaya bahasa paralelisme sebanyak 20 buah.

Selanjutnya saran atau rekomendasi yang dapat diberikan berkenaan dengan penelitian ini, bagi guru, guru hendaknya memilih metode pembelajaran yang tepat untuk pembelajaran puisi, sehingga siswa dapat mengapresiasikan pusi tersebut. Guru harus mbenar-benar mengari siswa tentang struktur puisi sebaik mungkin agar siswa lebih memahami, khususnya mampu membuat puisi dengan baik. Guru boleh saja mengikutsertakan siswa atau melibatkan siswa ke dalam pembelajaran di luar kelas agar dapat termotivasi membuat puisi dengan baik berdasarkan medan/objek yang dilihatnya. Dalam hal ini, memberikan perbaikan pembelajaran agar siswa tidak merasa bosan belajar hanya di dalam keas.

Selanjutnya, siswa, dalam hal ini juga harus lebih sering berlatih membuat puisi dan sering membaca buku kumpulan puisi. Diusahakan pula banyak bertanya terhadap unsur puisi atau sesuatu yang berkenan dengan puisi. Jangan malas atau malu bertanya agar mendapatkan pengetahuan yang memadai tentang seputar puisi dan penuisan puisi dengan baik. Kemudian bagi piha sekolah juga sebaiknya sering mengikutsertakan siswanya dalam kegiatan-kegiatan yang berhubungan dengan sastra, seperti perlombaan, seminar, dan sebagainya. Di samping itu, diharapkan sekolah bisa bekerja sama dalam menyediakan fasilitas untuk siswa dalam memahami dan mampu membuat puisi dengan baik.

\section{DAFTAR PUSTAKA}

Djojosuroto, K. (2005). Puisi: Pendekatan dan pembelajaran. Bandung: Nuansa. Emzir. (2010). Metode penelitian kualitatif: Analisis data. Jakarta: Rajawali Press. Finoza, L. (2008). Komposisi bahasa Indonesia. Jakarta: Diksi Insan Mulia. 
Keraf, G. (2007). Diksi dan gaya bahasa. Jakarta: Gramedia.

Keraf, G. (1994). Komposisi: Sebuah pengantar kemahiran bahasa. Ende: Nusa Indah.

Nurgiyantoro, B. (2009). Teori pengkajian fiksi. Yogyakarta: Gadjah Mada University Press.

Tarigan, H. G. (2009). Pengajaran gaya bahasa. Bandung: Angkasa.

Taum, Y. Y. (2011). Studi sastra lisan. Yogyakarta: Lamalera.

Wahyuningtyas, S., \& Wijaya, H. S. (2011. Sastra: Teori dan implementasi. Surakarta: Yuma Pustaka. 